\title{
Soft planning for soft spaces. Concept of Poznań metropolitan area development - a case study
}

\begin{abstract}
The article presents the essence, goals and instruments of soft (informal, non-statutory) spatial planning, developed in the countries of Western Europe and relatively new in Poland. It targets areas with fuzzy borders (soft spaces) and areas between administration tiers. The article presents conceptual issues and non-formal planning tools used in Western Europe. The planning approaches which are generally described as "soft" are characterised by non-formalised and non-binding procedures, and by their focus on achieving a consensus. In the first part of the article presents the conceptual issues and further informal planning instruments used in Western European countries at different spatial scales The following section presents deficits of spatial planning of metropolitan areas and against this background - the legitimacy of creating informal plans in Poland, using Metropolia Poznań as an example
\end{abstract}

\section{Keywords}

Spatial planning $\bullet$ soft spaces $\bullet$ metropolitan area $\bullet$ governance $\bullet$ territorial contract • Poznań Metropolitan Area

(C) University of Warsaw - Faculty of Geography and Regional Studies
Tomasz Kaczmarek

Institute of Socio-Economic Geography and Spatial Management, Faculty of Geographical and Geological Sciences, Adam Mickiewicz University, Poznań, Poland e-mail: tomkac@amu.edu.pl

\section{Introduction}

At least two decades have passed since the change of the governing paradigm in the field of politics and public administration in European countries and since the transition from the Weberian or neo-Weberian model of governing to the model of governance (Rhodes 2000; Kettl 2002). Changes in the territorial management paradigm, which take into account the cooperation and consensus of many stakeholders, can also be found in the sphere of spatial planning. Haughton et al. (2010) provide the following factors as evidence of the development of governance in spatial planning:

- the increase in spatial conflicts and the growing complexity of the spatial planning process (observed since the mid1970s);

- the impermeability of spatial planning systems and inflexible legal solutions;

- the inflexibility of administrative structures and the creation of new kinds of spaces of flows and soft spaces);

This article focuses on a relatively new approach to spatial planning, namely soft (informal) planning, as one of the tools for devolving and socializing the territorial governance process. The successive chapters present the essence, goals and instruments of non-statutory (informal) spatial planning, which is relatively new in Poland and well developed in highly developed countries.

The aim of the first part of the article is to present the essence, functions and instruments of informal spatial planning applied in Western European countries in relation to areas not covered by formal management and planning structures. The second part of the article presents the premises and the idea of developing the Concept of Directions of Spatial Development of the Poznań Metropolitan Area (Kaczmarek \& Mikuła 2016). This document is an interesting example of informal spatial planning, which is still uncharted territory in Poland. Its task is to bridge the gap between the poorly defined and legally validated metropolitan planning of the voivodship self-government and local planning. The concept was created by

a territorial contract of communes - members of the Metropolia Poznań Association. It is binding in the creation of directional spatial policies of local self-governments. In 2017, this document was granted the Prime Minister's Award. The jury of the competition recognized it as a model for other metropolitan areas in Poland. In the summary, the above document is used to demonstrate the strengths and weaknesses of informal planning as a tool for conducting spatial policy on a supra-commune scale.

Essence and goals of soft spatial planning

Haughton et al. (2010) introduced the term "new spatial planning", which in comparison to earlier forms of space management, is marked by features such as:

- devolution of ideas and ways of thinking about space management from the European and international level to the national, regional and local levels;

abandoning the sectoral ("silo") approach in spatial planning for the sake of integrated planning that combines functional, spatial, economic, social, and ecological aspects;

- basing the planning process on coordination and negotiation, even if it extends the process itself and makes it more complex and complicated; 
- increasing efforts to assess and monitor the effects of planning decisions and their enforcement;

a growing variety of practices and planning instruments aimed at the de-formalization, decentralization and socialization of the planning process.

The following part of the article focuses on the last of the aforementioned elements of a new approach to spatial planning, namely soft (informal) planning, as a tool for decentralizing and socializing the territorial management process. Soft planning, which is already developed in the countries of Western Europe, is not yet well known or widespread in Poland; hence the need to discuss its essence and goals. Table 1 presents selected characteristics of informal planning against the background of formal planning. Although the dichotomy presented in it is not completely unambiguous, it helps to define in a succinct way the basic differences between the two types of planning.

"Informal planning", also known as "soft planning", is a term used in reference to planning which is not based on legal or financial instruments and only concerns informal forms of action and implementing shared visions (Waterhout 2010). Informal planning is also often referred to as non-statutory, as it refers to voluntary planning procedures that are not contingent on planning regulations and are not binding.

An important goal of informal planning is to avoid or mitigate potential conflicts through cooperation processes, even before implementing legally binding planning studies (Planungsbegriffe in Europa 2003). Informal planning, which is targeted at achieving consensus, is also treated as the pre-planning process, or the planning of planning. Interestingly, as it is more indefinite, informal planning may focus on both spatial and functional links between socio-economic activities in specific areas. It can therefore be applied in the implementation of the model of integrated planning, which Markowski (2013) defines as being concentrated on the major social, economic and spatial problems of a given area. Soft planning is considered to be one of the tools of governance. It should be based on a contract which binds development process partners, and specifies mutual obligations and interdependencies as well as unwritten rules of conduct within the mutually approved axiological consensus. The standards supporting the contracting processes stress the importance of cooperation that respects solidarity and reciprocity, and include, among others: striving for integration, reciprocity of services, shared creation of standards and development planning, as well as programming (Macneil 1974; Stankiewicz 2012; Noworól 2017)

\section{Soft spaces as spatial planning entities}

Informal spatial planning is primarily addressed to areas with ambiguous borders and to planning areas between administrative tiers (Haughton et al. 2010). The relevant literature calls these "soft spaces". Allmendinger \& Haughton (2009), defines soft spaces as areas where deliberate attempts are made to introduce new and innovative ways of thinking, especially in places where there is considerable resistance to cross-sectoral and inter-territorial governance. Walsh et al. (2012) consider them to be special kinds of spaces, across political and administrative boundaries and beyond the internal territorial division of the state. These are areas - a kind of "multi-zone" - created for strategy and policy implementation, and visible on various planning scales outside the structures of statutory planning (Allmendinger \& Haughton 2009). According to the above authors, the appearance of such "soft spaces" is an important trend that is related to the impetus of a policy of detachment from preexisting frameworks and patterns of activities that do not reflect real geographical problems.
Table 1. Hard (formal) spatial planning versus soft (informal) spatial planning: selected features

\begin{tabular}{|c|c|}
\hline $\begin{array}{l}\text { Hard spatial planning } \\
\text { (formal) }\end{array}$ & $\begin{array}{l}\text { Soft spatial planning } \\
\text { (informal) }\end{array}$ \\
\hline Statutory & Non-statutory \\
\hline Mandatory & Voluntary \\
\hline Procedural & Outside official procedure \\
\hline Normative & Conceptual, analytical \\
\hline Regulatory, enforceable & Postulative, recommended \\
\hline Hierarchical & Non-hierarchical \\
\hline At a certain planning level & Between tiers \\
\hline $\begin{array}{c}\text { For units within } \\
\text { administrative boundaries }\end{array}$ & Trans-border, inter-border \\
\hline Of limited participation & $\begin{array}{c}\text { By / among stakeholders, } \\
\text { participatory }\end{array}$ \\
\hline Created by authorized offices & $\begin{array}{c}\text { Created by other organizations } \\
\text { also }\end{array}$ \\
\hline $\begin{array}{l}\text { Poorly integrated with socio- } \\
\text { economic planning }\end{array}$ & $\begin{array}{l}\text { Possibilities of integration with } \\
\text { socio-economic planning }\end{array}$ \\
\hline
\end{tabular}

Source: own study

The concept of soft spaces is linked with the term "fuzzy boundaries". The recent erosion of state, regional and local borders is the result of increasing mobility of people, goods and capital (spaces of flows), and the overlapping of problems, including spatial development problems and especially those of a network character. Such areas include border areas, especially in the European Union Member States, metropolitan areas covering cities within administrative boundaries and extensive suburban zones, as well as other functional areas related to a specific type of development. Soft spaces appear on the international scale (large transborder regions in Europe, euro-regions and euro-cities) and on the national scale, including regionally (e.g. tourist regions), sub-regionally (urban functional areas, national parks, landscape parks), and locally (functional microregions). For the above spaces there is a need to create planning studies (concepts, blueprints, structural plans, framework plans, etc.).

The informal spatial planning process leads to specific documents (plans) being adopted that fulfil various functions at various levels of operation of public authorities: they inform and educate, support integration processes and, finally, limit potential conflicts. On the European scale, ESPON studies are examples of such plans; on the cross-border scale these are studies of spatial development of border zones (euro-regions, euro-cities). In the latter case, valuable lessons can be learned, among others, from the borderland of Germany and the Netherlands, where common planning documents are created for cross-border areas (e.g. Aktionskarte Raumentwicklung über Grenzen).

Metropolitan regions are a particular challenge for informal planning. In many European countries such regions are not subject to statutory spatial planning; at best they are part of regional planning (see Kaczmarek \& Mikuła 2007; Mandel 2008). As Preising (2012) observes, the development of metropolitan regions as domestic economic nodes, like that of strictly administrative units, should be based on the normative objectives of regional development and subject to spatial planning regulations. Their objective should be integrated and sustainable development that serves the long-term development of the spatial potential of metropolitan regions. 
In Europe, there are no uniform solutions in the field of integrated metropolitan government. They have a strong national and even regional character adapted to the political, historical and economic uniqueness of a given country. There are few metropolitan areas that function as local government units (metropolitan government). A case in point is the Hanover region, which since 2002 has included structures governing - in an integrated way - both the city and the suburban area. Under the law on spatial planning (Raumordnungsgesetz - ROG), the Hanover region is obliged to create the Regional Spatial Planning Program (Regionales Raumordnungsprogramm - RROP). Most metropolitan areas in Europe are trying to solve management and planning problems within the formula of metropolitan governance (e.g. the città metropolitana in Italy, the metropolitan area in Portugal and Spain, the metropolitan county in England, the Metropolregion in Germany, and the métropole in France). Compared to the above European countries, Poland is at the beginning of the road of making metropolitan areas major actors in the planning and governing process (more on this question in Porawski [ed. 2013])

Metropolitan areas in Poland as a challenge for spatial planning

The metropolitan area of the city is a new entity of development policy, and is indicated in the Concept of Spatial Development of the Country 2030 (2012). According to this Concept, due to the complexity of socio-economic and spatial issues and due to the need to increase the coordination and efficiency of public activities, functional urban areas must apply special planning solutions, development strategies and spatial development plans.

For around 10 years, discussions have been taking place in Poland as to the introduction of statutory solutions which would sanction the separation of metropolitan areas in the territorial government system. Dynamic suburbanization processes occurring mainly around the largest cities of the country create new issues for spatial policy; these cannot be resolved under the existing planning model. This has long been criticized (Billert 2006, Lisowski \& Grochowski 2007; Jędraszko 2008). The negative financial consequences of uncontrolled suburbanization are increasingly underlined. It is the result of the disintegration of planning at the supra-local level and of the almost unlimited freedom in spatial policy at the municipal level (Raport o ekonomicznych stratach... 2013; Śleszyński 2014). The achievements of metropolitan governance in Poland have been quite moderate so far and very modest in the area of spatial planning. The significant importance attributed to metropolitan planning in scientific studies and strategic documents is not reflected in the applicable legal regulations. Currently, they place metropolitan planning as part of regional planning under the auspices of the urban development plan of the functional area (acc. to the Polish Law on spatial planning and development). Analysis of the legal planning grounds indicates that one could actually doubt the practical effectiveness of metropolitan planning from the regional level. These regulations are rather concise and imprecise, both as to the delimitation of functional areas and as to the procedure for preparing and adopting the urban plan of the functional area. The role of local government units is limited only to consultations, which the Law does not define precisely in terms of form or scope. The constitutional status of communes and their strong planning powers basically exclude their hierarchical subordination to the voivodship self-government in the field of spatial planning (more on this matter in Mikuła 2016). Moreover, an important problem with the current model is the fact that spatial planning must correspond to the division of public tasks into regional and local ones. Greater opportunities in this area could be gained by creating a new metropolitan planning entity, i.e. a planning union of communes. This solution is known and widely used in some Western European countries, such as Germany (Planungsverbände, Regionalverbände).

Current legal regulations transfer metropolitan planning from the regional level to the level of local territorial unions. So far, only one metropolitan union has been established in the Śląskie Voivodship with a statutory task of spatial planning. Waiting for specific legal instruments to integrate spatial planning in metropolitan areas or the legal constitution of their unions, the only rational solution is for cities and communes to cooperate voluntarily in this area. According to Delcamp (1997) "cooperation is the answer that the state or intermediate structures, or the local communities themselves are trying to give for the inadequacy of institutions to economic and social realities."

Concept of Poznań Metropolitan Area Development: an example of soft planning

The functional area of Poznań is an example of a bottomup access path to integrated planning in the metropolitan area. Since 2010, the Metropolia Poznań Association has been in operation there, which contributes to the process of creating self-government organizational ties in the political, economic and social aspects. In the Report on the Condition of Polish Cities (eds Janas \& Jarczewski 2017), the Metropolia Poznań was defined as the national leader in the integration of governance in urban functional areas. In the short period of its existence, the Metropolia Poznań Association has developed a soft document of strategic planning: "Strategy for the development of the Poznań Agglomeration. The Metropolis of Poznań 2020" (2011). It contains 5 axes and 22 strategic programs. One of the currently implemented goals of the strategy is the integration of public transport and the creation of a Poznań Metropolitan Railway. In 2015, the Association became a beneficiary of Integrated Territorial Investments supporting integration in the metropolitan area, specifically in the field of public transport.

In 2015, the Association undertook to develop a coherent, area-specific concept of spatial development of the metropolitan area of Poznań (this program was recorded as strategic in the aforementioned document from 2011). Thus, the local authorities deemed it necessary to create an informal document that would fill the gap between the still poorly defined regional planning of the voivodship self-government and local planning. As to its scope, the Concept covered the area of Poznan and spatially and functionally connected 21 communes, forming a monocentric Poznań agglomeration together with the city. As of 2016, this area covers $3,082 \mathrm{~km}^{2}$ and is inhabited by nearly $1,300,000$ persons, which constitutes $10 \%$ of the area and $30 \%$ of the population of Wielkopolskie Voivodship.

In accordance with its provisions, the Concept of Spatial Development Directions of the Poznań Metropolitan Area (Kaczmarek \& Mikuła 2016) ${ }^{1}$ has four basic functions:

1. Diagnostic, i.e. recognizing the spatial structure of natural resources and socio-economic potentials of the Metropolis of Poznań, presenting the distribution and dynamics of phenomena in key areas of its functioning. Moreover, the document identifies spatial policies implemented by communes and the coherence of the planning documents they develop at the scale of the entire metropolis.

2. Applicable (indicative), by pointing out the key problems of spatial development, spatial development deficits on the scale of the whole agglomeration and ways of solving them through directional actions combined with implementing them into the communes' planning practice.

${ }^{1}$ The Concept project was partly financed by the European Union under the Operational Program Technical Assistance 2007-2013. 
3. Awareness-raising, i.e. gathering a thematic set of spatial information, so far limited to communal areas, thus enabling monitoring of the situation and spatial changes on the scale of the entire metropolis.

4. Educational, constituting a source of knowledge about the state and mechanisms of spatial development of the Metropolis of Poznan during the period of intense suburbanization, and shaping metropolitan thinking in local spatial planning.

The Concept of the Spatial Development Directions of the Poznań Metropolis includes, among others:

- Principles of spatial development of the Metropolis of Poznań based on the guidelines of national spatial policy documents (KPZK 2030), including first of all the concept of a "compact city" and energy-efficient spatial structure,

- Indication of areas that are important from the point of view of environmental protection and cultural landscape, including areas with a development ban envisaged, those proposed for different forms of environmental protection and those designated for afforestation,

- Indication of activities aimed at integrating the management of water resources and waste management in the metropolitan area,

- Defining the directions of development of tourist areas, in particular the Warta River valley,

- Indication of priority areas for the development of housing, services and production, based on analysis of the absorptive capacity of the areas and the possibility of equipping them with the necessary technical infrastructure,

- Indication of degraded areas requiring urgent revitalization activities,

- Directions of public transport development, bicycle infrastructure, development of road network and directions of the railway network development, mainly based on the metropolitan railway concept,

- Directions of development for technical infrastructure and the location of metropolitan social infrastructure facilities,

- Accessibility analysis and indication of possible new locations for large-area shopping facilities.

Implementation of the provisions of The Concept of Spatial Development Directions of the Poznań Metropolitan Area takes place primarily within the existing institutional system, i.e. based on the municipal and city self-governments and the Metropolia Poznań Association. Under two resolutions, the Metropolia Poznań Association Council adopted the Concept of Spatial Development Directions of the Poznań Metropolitan Area and recommended its use to its members in the work on local spatial policy documents. $^{2}$ In April 2017, the Metropolitan Planning Commission was established. It is unique in Poland, where only urban and architectural commissions operating to the agendas of territorial self-government units (in communes and voivodships) operate. This Commission, composed of planners, scholars and local government officials, is the body that gives opinions on the study of conditions and directions for the spatial development of communes. Due to its short period of operation, it is now difficult to determine the effectiveness of the Commission in enforcing the compliance of local spatial policies with the provisions of the metropolitan document.

The generally introduced Concept of Spatial Development Directions of the Poznań Metropolitan Area has, then, the

\footnotetext{
${ }^{2}$ Resolution No. 6/2017 of the Metropolitan Council of the Metropolis Poznań Association of February 21, 2017 regarding the adoption of the Concept. Resolution No. 7/2017 of the Metropolitan Council of the Metropolis Poznań Association of February 21, 2017 regarding the appointment of the Metropolitan Planning Commission
}

following fundamental features of an informal planning document:

it is not an act of law and does not arise from the law currently in force,

it was drawn up by a team of scholars and urban plannerspractitioners, in close cooperation with local self-government units,

work on the concept involved meetings and debates within permanent conferences of the Metropolitan Forum of Spatial Planning with the participation of various stakeholders, incl. representatives of communes and the third sector,

the draft document went through consultation with inhabitants of communes to which the Concept was related during 22 meetings in units of territorial self-government of the Poznań Metropolis,

the Concept is being implemented under a contract - an agreement between the members of the Metropolia Poznań Association,

in the event of establishing a metropolitan union with an assigned power to plan on the supra-local level, the Concept may be a major program foundation document (pre-planning function) for the adoption of a statutory planning document (Framework study of the conditions and directions of spatial development of a metropolitan union).

In October 2017, the Concept was awarded a prestigious academic prize of the Prime Minister in the category of scientific and technical achievements. In its justification, the jury of the competition considered this type of study to be a model for other metropolitan areas in Poland.

\section{Conclusion}

The publications presented at the beginning of the article stress the need for informal planning primarily in relation to soft spaces, trans-border areas or areas with poorly marked borders, such as metropolitan areas (Allmendinger \& Haughton 2009). With respect to spatial planning, hard spaces - national, regional and local - provide forms of electoral accountability for creating and implementing statutory plans. However, as Metzger \& Schmitt (2012) emphasize, although the binary division of planning into formal and informal is useful for heuristic purposes, in practice it is often less pronounced thanks to the growing role of informal consensus-based documents.

Theoretical considerations still perceive informal spatial development plans as spatial planning scenarios. Undoubtedly, such a view is beneficial both for the status of spatial planning itself and for the effectiveness of spatial policy and its place in the public governance system. A real strengthening of such spatial planning would be possible only after appropriate changes were made in the regulations that would strengthen the impact of this planning area on other mechanisms of public authorities' influence on the socio-economic reality. Recognizing informal planning as part of the planning system, and perhaps also as a stage in the planning process, would probably strengthen its decision-making position, so that informal spatial planning, too, would be an effective spatial policy tool.

The Concept of Spatial Development Directions of the Poznan Metropolis presented in the article is an example of informal spatial planning in Poland. This document is only at the beginning of the implementation stage and so it is difficult at this point to assess its usefulness and effectiveness. The agreement concluded as to following the document's provisions in the implementation of spatial policy in communes is similar to the contract method. According to MacNeil (1974, after Stankiewicz 2012) the contract creates circumstances in which the individual, economic (material) interests of each party should be 
Table 2. Strengths and weaknesses of informal spatial planning

\begin{tabular}{|l|l|}
\hline Advantages / opportunities & \multicolumn{1}{|c|}{ Deficits / threats } \\
\hline - Planning for areas for which & - Poor awareness among \\
there is no mandatory & decision makers of the \\
planning requirement & need for informal plans \\
- The process of learning & - Poor planning culture, \\
and further tightening & frequent discounting on the \\
cooperation & part of the planning sector \\
- Creation of a shared spatial & - Limited power of informal \\
database & plans \\
- Inspiration for creating & - The necessity of a \\
sectoral programs, & contract at the stage of \\
masterplans, etc. & implementing arrangements \\
- Possible element of the & and recommendations \\
planning system - Pre- & - Long-term effect, which \\
planning & does not meet current \\
- Possible / desirable broad & expectations (e.g. political) \\
public participation. & \\
\hline
\end{tabular}

Source: own study

\section{References}

Allmendinger, P \& Haughton, G 2009, 'Soft Spaces, Fuzzy Boundaries, and Metagovernance: The New Spatial Planning in the Thames Gateway', Environment and Planning, A., vol. 41, issue 3, pp. 617-633.

Billert, A 2006, 'Planowane przestrzenne a polityka. Trzecia droga do trzeciego świata (Physical planning and politics. A third way to the third world)', Urbanistyka $w$ działaniu. Teoria i praktyka. Biblioteka Urbanisty, no. 9, pp. 240-253.

Delcamp, A 1999, La cooperation intercomunale en Europe. L'intercomunalite - balance et perspectives, PUF, Paris.

Haughton, G \& Allmendinger, P 2008, The Soft Spaces of Local Economic Development, Local Economy, vol. 23, pp. 138148.

Haughton, G, Allmendinger, P, Counsell, D \& Vigar, G 2010, The New Spatial Planning: Territorial Management with Soft Spaces and Fuzzy Boundaries, Taylor \& Francis, London.

Janas, K \& Jarczewski, W (eds) 2017, Raport o stanie polskich miast. Zarządzanie i współpraca w miejskich obszarach funkcjonalnych (Report on the conditions of Polish cities. The management of urban functional areas), Obserwatorium Polityki Miejskiej, Instytut Rozwoju Miast, Kraków.

Jędraszko, A 2008, 'Gospodarka przestrzenna w Polsce wobec standardów europejskich czyli jak ustanowić dobre prawo dla zrównoważonego rozwoju, (Spatial management in Poland against European standards)', Biblioteka Urbanisty, no.13, Urbanista, Warszawa.

Koncepcja Przestrzennego Zagospodarowania Kraju (KPZK) 2030 (Concept of Spatial Development of the Country 2030) 2012, Monitor Polski (poz. 252).

Kaczmarek, T \& Mikuła, Ł (eds) 2016, Koncepcja Kierunków Rozwoju Przestrzennego Metropolii Poznań (Concept of Directions of Spatial Development of the Poznań Metropolitan Area), Centrum Badań Metropolitalnych, Uniwersytet im. Adama Mickiewicza w Poznaniu.

Kaczmarek, T \& Mikuła, $Ł$ 2007, Ustroje terytorialnoadministracyjne obszarów metropolitalnych w Europie (Territorial and administrative systems of metropolitan areas in Europe), Bogucki Wydawnictwo Naukowe, Poznań.

Kettl, DF 2002, The Transformation of Governance. Public Administration for Twenty-first Century America., John Hopkins University Press, Baltimore. subordinated to a long-term development policy, often conflicting with each short-term desire to maximize individual utility. Over time, however, acts made in the name of far-reaching motivations produce standards to which decision-makers attach themselves and expect such attachment of other entities as parties to the contract. Based on the analysis of creating and implementing the Concept, we can indicate the strengths and weaknesses of this type of planning (Table 2).

It is obvious that informal planning cannot be a substitute for formal planning if binding actions and decisions are considered as a planning goal. New flexible instruments can never replace classic plans, but they can complement them and thus contribute to the implementation of planning goals. Informal instruments, based on the voluntary involvement of the stakeholders in the planning process, can significantly contribute to the implementation of formal instruments to instigate programmes that supersede or complement classic plans.

Lisowski, A \& Grochowski, M 2007, Procesy suburbanizacji. Uwarunkowania, formy i konsekwencje (Suburbanization processes. Conditions, forms and consequences.) Opracowanie przygotowane na zlecenie Ministerstwa Rozwoju Regionalnego, Warszawa.

Mandel, K 2008, 'Regional Governance - Made by RheinNeckar: das neue Organisationsmodell für die Region' in Metropolregionen in Deutschland: 11 Beispiele für Regional Governance, eds. J Ludwig, K Mandel, C Schwieger \& G Terizakis, Baden-Baden, pp. 130-142.

Macneil, IR 1974, 'The many futures of contracts', Southern California Law Review, no. 47, pp. 691-816.

Markowski, T 2013, 'Territorial dimensions of integrated development policy - expectations and challenges concerning planning and institutional systems', Studia Regionalia, no. 35, pp. 51-64.

Metzger, J \& Schmitt, P 2012, 'When soft spaces harden: the EU strategy for the Baltic Sea Region', Environment and Planning A, vol. 44, pp. 263-280.

Mikuła, $Ł$ 2016, 'Nowe uregulowania prawne planowania metropolitalnego w Polsce (New legal regulations for metropolitan planning in Poland)', in Integracja planowania przestrzennego w Metropolii Poznań - problemy, metody, osiagnięcia, ed. Ł Mikuła, Biblioteka Aglomeracji Poznańskiej, no. 27, Bogucki Wydawnictwo Naukowe, Poznań, pp. 13-24.

Noworól, A 2017, 'Kontrakt jako instrument zarządzania obszarami funkcjonalnymi. (The contract as an instrument of functional area management)' in Teoria i praktyka rozwoju obszarów funkcjonalnych, eds T Kudłacz \& P Brańka, Studia KPZK PAN, vol. CLXXIV, pp. 86-96.

Planungsbegriffe in Europa, Deutsch-Niederländisches Handbuch der Panungsbegriffe 2003, ARL.

Porawski, A (ed.) 2013, Współpraca jednostek samorządu terytorialnego w Polsce. Stan i potrzeby (Cooperation of local government units in Poland. State and requirements), Związek Miast Polskich, Poznań.

Preising, T 2008, 'Metropolregionen - ein fragender Blick. Potenziale und Perspektiven für die räumliche Planung', Planerin, vol. 1, pp. 36-37.

Raport o ekonomicznych stratach i społecznych kosztach niekontrolowanej urbanizacji w Polsce (Report on economic 
losses and social costs of uncontrolled urbanization in Poland) 2013, Fundacja Rozwoju Demokracji Lokalnej.

Rhodes, RA 2000, Debating Governance, Oxford University Press, Oxford.

Stankiewicz, W 2012, Ekonomika instytucjonalna. Zarys wykładu, Wydawnictwo Prywatnej Wyższej Szkoły Businessu, Administracji i Technik Komputerowych, Warszawa.

Śleszyński, P (ed.) 2014, Analiza stanu i uwarunkowań prac planistycznych w gminach w 2014 r. (Analysis of the conditions of planning works in communes in 2014), opracowanie na zlecenie DPP MliB, PAN IGiPZ, Warszawa.

Walsh, C, Jacuniak,-Suda, M, Knieling, J \& Othengrafen, F 2012, Soft Spaces in Spatial Planning and Governance: Theoretical Reflections and Definitional Issues, Regional Studies Association European Conference, Delft, 13-16 May 2012.

Waterhout, B 2010, Soft Spaces and Governance: The Transformation of Planning, 24th AESOP, Annual Conference, Helsinki, 7-10th July 2010. 